\title{
Population dynamics of the yellow clam Mesodesma mactroides: recruitment variability, density-dependence and stochastic processes
}

\author{
Mauricio Lima $^{1, *}$, Alejandro Brazeiro ${ }^{2}$, Omar Defeo ${ }^{2,3}$ \\ ${ }^{1}$ Departamento de Ecología, Pontificia Universidad Católica de Chile, Casilla 114-D, Santiago, Chile \\ ${ }^{2}$ UNDECIMAR, Facultad de Ciencias, Universidad de la República, Casilla 10773, 11400 Montevideo, Uruguay \\ ${ }^{3}$ CINVESTAV IPN Unidad Mérida, 97310 Mérida, Yucatán, Mexico
}

\begin{abstract}
Recruitment of benthic marine invertebrates varies greatly at different spatio-temporal scales. For instance, population dynamics of the yellow clam Mesodesma mactroides at Uruguay exhibit large temporal fluctuations, mainly associated with recruitment. We used data from an 8 yr long-term study to develop an age-structured model to show that density-dependent and densityindependent forces acting together can jointly explain the population fluctuations in a sandy-beach bivalve population of the yellow clam Mesodesma mactroides. The pure density-dependent deterministic model parameterised with empirical values estimated during the $8 \mathrm{yr}$ study predicted stable dynamics. The dynamics of the deterministic skeleton was markedly influenced by the addition of a relatively small amount of stochastic variability to fertility rates. The yellow clam population dynamics seem to be driven by the combined forces of density-dependent and density-independent factors operating together. A combination of (uncorrelated) stochasticity in reproductive rates and asymmetric intercohort interactions (density-dependent recruitment and density-dependent survival rates) seems to be the key process generating large variability in recruitment.
\end{abstract}

KEY WORDS: Mesodesma mactroides $\cdot$ Oscillations $\cdot$ Recruitment variability $\cdot$ Age-structured model Marine invertebrates $\cdot$ Intercohort interactions

\section{INTRODUCTION}

One of the key issues in population ecology is to distinguish the relative importance of density-dependent and density-independent factors in population dynamics (Nicholson 1933, Andrewartha \& Birch 1954, Royama 1992). Traditionally, there have been 2 opposing views of population dynamics, one perceiving population changes as being determined by density-independent (e.g. climatic) factors only (Bodenheimer 1938, Andrewartha \& Birch 1954), the other stating that only density-dependent factors regulate population dynamics (Nicholson 1933). Although ecologists from both

*E-mail: mlima@genes.bio.puc.cl schools have long debated hotly, a synthesis seems to have arisen during the last decade representing a 2dimensional view of population dynamics, one focused on external, density-independent disturbances, the other on intrinsic system-density-dependent dynamics (Turchin \& Taylor 1992, Turchin 1995). Nowadays, it is generally accepted that the dynamics of natural populations are explained by the interaction of both environmental and density-dependent factors (Royama 1992, Higgins et al. 1997a,b, Leirs et al. 1997, Lima et al. 1999).

Most marine benthic invertebrates have complex life cycles with a planktonic larval stage (Thorson 1950, Gaines \& Roughgarden 1985). Hence, larval dispersal, settlement and recruitment processes may play a fundamental role in determining their population dyna- 
mics (Underwood \& Denley 1984, Connell 1985, Gaines \& Roughgarden 1985, Hughes 1990, Sutherland 1990, Menge 1991, Bertness et al. 1992, Peterson \& Summerson 1992, Nakaoka 1993). Recruitment of benthic marine invertebrates is largely variable at different spatio-temporal scales (Guillou 1982, Vahl 1982, Bachelet 1986, Rumrill 1989, Raimondi 1990, Pearson \& Munro 1991, Nakaoka 1993, Defeo 1996a, Hunt \& Scheibling 1997, Pineda \& Caswell 1997). Many authors have suggested that large-scale change in oceanographic conditions, winds, temperature, salinity and other environmental forces could generate variability in mortality during pre and early post-settlement stages, thus affecting temporal and spatial patterns of recruitment (Botsford 1986, Arntz et al. 1987, Pineda 1991, Cushing 1995).

On the other hand, recruitment variability could also occur as a result of system-intrinsic (density-dependent) mechanisms operating at smaller spatial scales (Hunt \& Scheibling 1997 and references therein). In this vein, inter-age or inter-stage density-dependent interactions are ubiquitous in marine invertebrates with overlapping generations (see Defeo 1996a and references therein). In such cases, resident adults reduce settlement and subsequent recruitment rates by either filtering settling larvae out of the water column or seizing available space (André \& Rosenberg 1991, André et al. 1993).

Several theoretical and empirical studies (Gurney et al. 1980, Nisbet \& Gurney 1982, Gurney \& Nisbet 1985, Desharnais \& Liu 1987, Liu \& Cohen 1987, Dennis et al. 1995, Shimada \& Tuda 1996, Constantino et al. 1997, Higgins et al. 1997a) have demonstrated that densitydependent interactions between different age or stage classes could generate a rich spectrum of deterministic dynamic behaviours. In particular, high and low frequency-dynamics may arise in Age 0 cod (Gadus morhua) populations by interaction between intraand intercohort density-dependence and stochasticity (Bjørnstad et al. 1999, Stenseth et al. 1999). However, there are few studies modelling such kinds of densitydependent systems in natural populations, especially in marine invertebrates (but see Nakaoka 1996, 1997, Botsford 1997, Higgins et al. 1997a,b).

Here we develop a mathematical model that includes density-dependence and stochastic processes to show that both forces can jointly explain the population fluctuations in a sandy-beach bivalve, the yellow clam Mesodesma mactroides. First, we describe the relationships between demographic parameters (i.e. age-specific survival and fertility) and population density. Second, we use these relationships to develop a density-dependent age-structured model. Third, we examine the dynamic behaviour predicted for the deterministic skeleton (i.e. density-dependent mecha- nisms). Finally, we analyse the effects of adding external stochastic perturbations to the model.

\section{MATERIALS AND METHODS}

The yellow clam life cycle. The yellow clam Mesodesma mactroides is one of the most common bivalve molluscs in the Atlantic sandy beaches of South America (Defeo 1989). It is a fast-growing, short-lived species, with a maximum life span of ca 3.5 yr (Defeo et al. 1992b). It presents a high fecundity (5300000 eggs female $^{-1}$ ) and a complex life cycle that includes a larvae phase with a variable pelagic stage (approx. 1 mo between the peak of mass maturation and recruitment to the beach: Masello \& Defeo 1986, Defeo 1996b), and a post-metamorphic benthic phase. The life cycle of the yellow clam can be divided into 4 age classes: (1) Age 0, recruits, which represent juvenile individuals settled in the intertidal zone after the larval stage from January to May, peaking in March and April (87\% of the total: Defeo et al. 1992b); (2), (3), (4) sexually ripe individuals. Mean size at first maturity is almost 43 mm (Masello \& Defeo 1986), corresponding approximately to the 1 yr-old individuals. Sex composition follows a 1:1 ratio (Masello \& Defeo 1986).

Study site. The most important population (highest densities) of Mesodesma mactroides on the Atlantic coast of Uruguay occurs in Barra del Chuy beach, a $22 \mathrm{~km}$ uninterrupted sandy coastal belt $\left(33^{\circ} 40^{\prime} \mathrm{S}\right.$, $53^{\circ} 29^{\prime} \mathrm{W}$ : Defeo et al. 1986, Fig. 1) enclosed by 2 water outlets, the Chuy stream and the Andreoni Canal. Barra del Chuy is a beach with a gentle slope (4\%) and fine sand (2.22 $\phi$ ) (Defeo et al. 1992a), and has the highest species diversity, total density and biomass of the sandy beaches of Uruguay (Defeo et al. 1992a).

Sampling design. Mesodesma mactroides population was monitored monthly from March 1983 to March 1985, and seasonally (at least 4 times a year) from 1985 to 1990. A systematic sampling design was employed: 22 equidistant transects, perpendicular to the shoreline, were set along Barra del Chuy beach; along each transect, sampling units (SUs) were obtained at $4 \mathrm{~m}$ intervals, from the base of the sand dunes to the shorelevel, where 2 successive SUs without clams were recorded (controls). The SUs were obtained with a corer, $28.2 \mathrm{~cm}$ in diameter and $40 \mathrm{~cm}$ in depth. Some 200 SUs were taken during each sampling period. Demography was independent of the sample location along the transects perpendicular to the shoreline: organisms, especially recruits and juveniles, are subject to swash-mediated movements and are mixing fairly periodically. Although the yellow clam does display some seasonal zonation patterns (Defeo et al. 
1986), it can be considered as consisting of perfectly mixed age/length groups without any remarkable zonation gradients across the beach for the purposes of this paper. Defeo $(1996 a, 1998)$ used this assumption during a long-term analysis of the fishery. The sediment of each sample was sieved separately through a $0.5 \mathrm{~mm}$ mesh, and all clams retained in each sample were measured (max. valve length) and counted. The full size range (1 to $76 \mathrm{~mm}$ ) was recorded for all sample periods, with $>100000$ individuals measured throughout the study. The annual dynamics of the yellow clam population is characterised by large variability in recruitment (Fig. 2).

Demographic data: survival and fertility estimates. Demographic estimates of Mesodesma mactroides were obtained from Brazeiro \& Defeo (1999). In that previous study, we estimated its annual age-specific survival probability and fertility during 8 consecutive

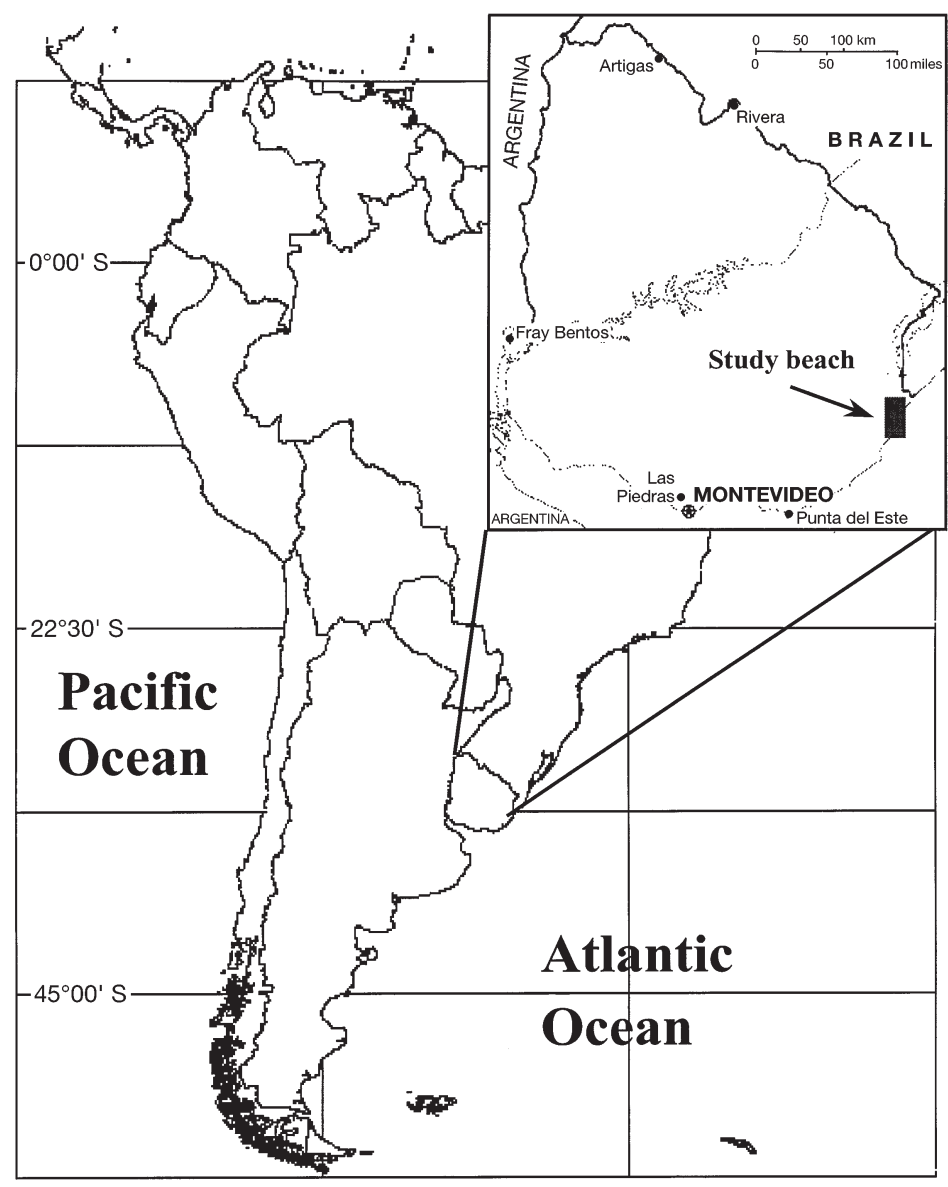

Fig. 1. Geographical location of study beach (Barra del Chuy), Uruguay. The most important population of Mesodesma mactroides on the Atlantic coast of Uruguay occur in Barra del Chuy beach, a $22 \mathrm{~km}$ uninterrupted sandy coastal belt $\left(33^{\circ} 40^{\prime} \mathrm{S}, 53^{\circ} 29^{\prime} \mathrm{W}\right.$ : Defeo et al. 1986). This beach is flanked by 2 water outlets, the Chuy stream and the Andreoni Canal. Barra del Chuy is a dissipative beach with a gentle slope $(4 \%)$ and fine sand $(2.22 \phi)$ years (1983 to 1990), using the methodology for postbreeding census developed by Caswell (1989). The following 2 paragraphs briefly summarise the estimation procedures (for details see Brazeiro \& Defeo 1999):

To obtain the annual age distribution, all individuals collected in each year, immediately after recruitment, were grouped into 5 age classes ( 0 to 4 ) according to the age-size key derived from a seasonal version of the von Bertalanffy growth model (Defeo et al. 1992b). The estimated relative abundance of each age class $\left(l_{i}\right)$ was employed to calculate the age-specific survival probabilities $\left(S_{i}\right)$, as follows:

$$
S_{i}=\frac{l_{i+1}}{l_{i}}
$$

Because the yellow clam population was not stationary, $S_{i}$ values were corrected by the observed population growth rate $(\lambda)$ recorded each year (see Eberhardt 1988). $S_{4}$ is zero because no individuals of Age Class 4 survive at the end of the 4 th year of life.

To estimate the fertility $(F)$, i.e. the average number of Age Class 0 individuals (recruits) generated per adult female, the number of recruits found in each year was partitioned among the corresponding reproductive females.

Density-dependent effects on reproductive and survival rates. We define the reproduction process as the transition from eggs through planktonic larvae to intertidal 0group individuals. This extended reproductive process is highly variable between years; the sources of this between-year variability may be associated with density-dependent individual interactions and stochastic variability. We modelled reproductive processes under 2 assumptions: (1) density-independent reproductive rate; (2) density-dependent reproductive rate. To allow stochastic variation in the reproductive process of the yellow clam, we used the following relationship:

$$
R_{t}=\mathrm{e}^{\alpha_{t}}
$$

where $\mathrm{e}^{\alpha_{t}}$ represents the per capita reproductive rate (number of yellow clam females produced by an adult female); we assume that $\alpha_{t}$ is normally distributed with mean $\alpha$ and constant variance $\left(\sigma_{\alpha}^{2}\right)$. We estimate the reproductive rate from data estimating mean and variance; under this assumption the per capita reproductive rate was log-normally distributed across years (Bjørnstad et al. 1999). Under a further assumption, we assumed that the reproductive rate is affected 


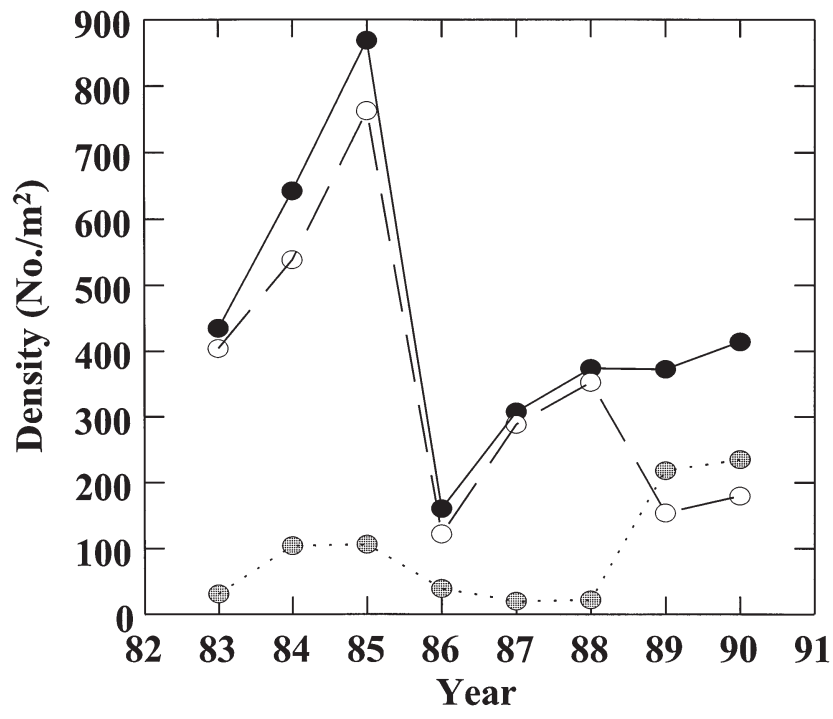

Fig. 2. Mesodesma mactroides. Population trajectories observed during the period 1983 to 1990: (- - ) total population, $(--\bigcirc--)$ recruits, and $(\cdots \bigcirc \cdots)$ adults

by density-dependent interactions. In previous studies, this yellow clam population has shown an overcompensatory stock-recruitment relationship (SRR) described by a Ricker (1954) model (Defeo 1996a, 1998). This model, which has been used to describe the SRR of molluscs (Hancock 1973) and beetles (Hastings \& Constantino 1987, 1991), suggests overcompensation (i.e. an inhibition of recruitment at high adult densities). Therefore, we modelled the reproductive rate as a negative function of adult population density at time $t\left(A_{t}\right)$;

$$
R_{t}=f\left(A_{t}\right)
$$

We used 3 different functional relationship to model density-dependence in reproductive rates: (1) a linear function; (2) a log-linear function; (3) an exponential negative function. The best model was selected using the small-sample corrected Akaike information criterion $\left(\mathrm{AIC}_{\mathrm{C}}\right.$ ) (Hurvich \& Tsai 1989, see Bjørnstad et al. 1995 for a detailed explanation in an ecological context). The most appropriate model will be that minimising the $\mathrm{AIC}_{\mathrm{C}}=-2 \log ($ likelihood $)+2 p+2(p+1)(p+2) /(n-p-2)$, where $p$ is the number of parameters and $n$ is the sample size. A difference of $\leq 1$ in the $\mathrm{AIC}_{\mathrm{C}}$ may be considered 'insignificant'; this represent a rule of thumb in AIC-based selection procedures (Sakamoto et al. 1986).

The density-dependent relationships on survival rates for each age-class was fitted using generalized linear models, GLM (McCullagh \& Nelder 1989); we used a binomial error structure and a logit link function. We tested if the number of recruits and/or the number of adults were better predictors of the agespecific survival rates, in order to determine the strength of the intra- and intercohort interactions in survival rates. In addition, we explored what type of functional relationship better describe the densitydependent effects on survival by using the predictor variable (density) in a linear or log-linear fashion at the logit scale. For example, Bjørnstad et al. (1999) demonstrated log-linear density-dependence in the survival rates of the Skagerrak coastal cod populations. We used the $\mathrm{AIC}_{\mathrm{C}}$ value to select the best models.

The age-structured model. In this paper, we used an age-structured model to formalise the life cycle of the yellow clam. Our starting point was the classical agestructured model of Leslie (1945) (see also Caswell 1989), but we included density-dependent and stochastic terms.

We initially assumed that the per capita egg production, hatching and survival to Age 0 was density-independent, but with stochastic variation. The per capita reproductive rate is given as a random variable (Engen \& Lande 1996, Stenseth et al. 1999). Also, we considered the Age Class 0 as individuals at the beginning of the benthic life, i.e. as recruits (Nakaoka 1993). Thus, the production of recruits of Age Class 0 in the Year $t+1$ is given by

$$
N_{0, t+1}=N_{1+2+3, t} \cdot \mathrm{e}^{\alpha} t
$$

where $N_{0}$ is recruit numbers, $N_{1,2,3}$ are adult numbers, and $\alpha_{t}$ is a sequence of normally distributed random variables, so that $\exp \left(\alpha_{t}\right)$ is log normal (Engen \& Lande 1996), given that recruitment variability is an important source of population uncertainty in marine benthic species (e.g. Raimondi 1990, Pineda \& Caswell 1997). On the other hand, assuming density-dependence in reproductive rates gives the following relationship for the number of recruits at time $t+1$;

$$
N_{0, t+1}=f\left(N_{1+2+3, t}\right) \cdot N_{1+2+3, t}
$$

where the function $f$ describes the functional relationship between the per capita reproductive rate and the adult population numbers. Intracohort and intercohort density-dependent interactions may reduce the survival of the individuals through the different age classes; the transitions across the different ages may be formalised by the following relationships;

$$
\begin{gathered}
N_{i, t+1}=N_{i-1, t} \cdot\left(\frac{1}{1+\mathrm{e}^{-\left(\beta-\gamma \cdot N_{0, t}-\mu \cdot N_{a, t}\right)}}\right) \\
N_{i, t+1}=N_{i-1, t} \cdot\left(\frac{1}{1+e^{-\left[\beta-\gamma \cdot \log \left(N_{0, t}\right)-\mu \cdot \log \left(N_{a, t}\right)\right]}}\right)
\end{gathered}
$$

where $\beta$, $\gamma$ and $\mu$ are positive constants determining the density-independent survival rate at low densities, and the reduction in survival due to density-dependent effects of the recruits and adults, respectively, and were estimated from the data. 


\section{RESULTS}

On the basis of a density-independent per capita reproductive rate Mesodesma mactroides adult female produce approx. 7.8 eggs that successfully hatch, metamorphose and enter the Age 0 group. However, there is a negative density-dependent effect on reproductive rates of the yellow clam (Fig. 3). A negative exponential model $\left[k \exp \left(-\beta N_{t}\right)\right]$ seems to describe well the functional density-dependent relationship of the density on reproductive rates, where $k$ is the maximum number of recruits produced by a female at low densities, $\beta$ is the density-dependent coefficient, and $N_{t}$ is adult density (Table 1, Fig. 3). The parameter estimates give a maximum of 18.45 recruits produced by a female at low adult densities; the negative, densitydependent coefficients $(k=-0.014)$ have a $95 \%$ CI that does not include 0 .

The linear functional relationship (at logit scale) appears to represent density-dependent effects on survival rates better than the log-linear. The parameter $\gamma$ that represents density-dependent effects of the Age 0 group is negative, and the $95 \%$ CI does not include 0 . In contrast, the parameter $\mu$, which represents the effects of adult density in survival rates, was both positive and negative and its $95 \%$ CI includes 0 (Table 2).

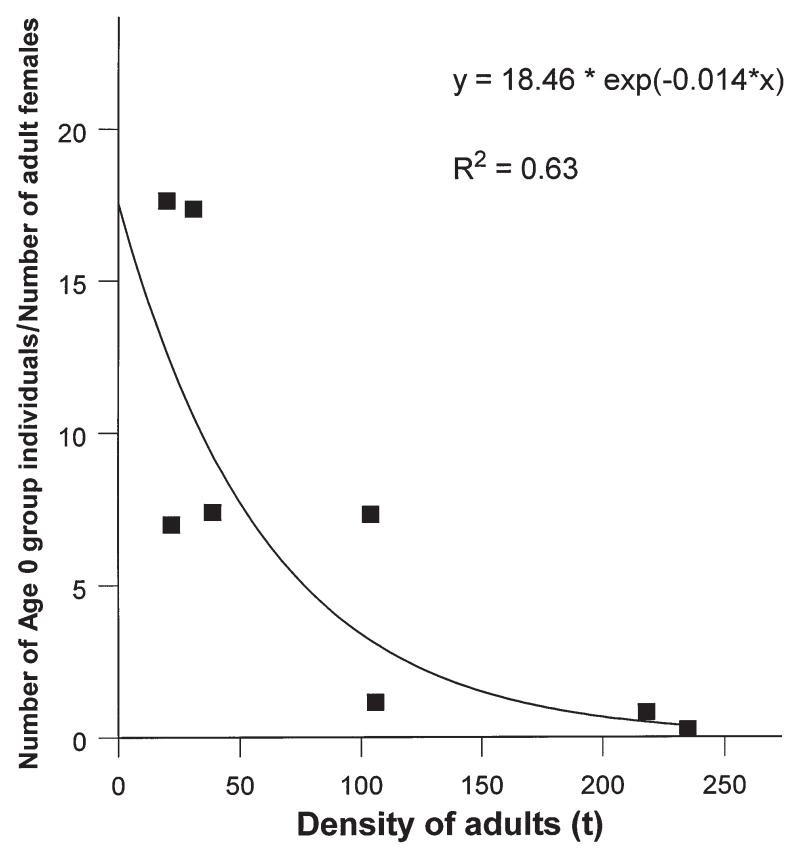

Fig. 3. Mesodesma mactroides. Best model fitted to relationship recruits (Age 0 individuals) produced by adult female and adult population density. Negative exponential model was best (using Akaike information criteria) for describing this relationship. Note that a negative model for the per capita reproductive rates gives rise to a Ricker's (1954) stockrecruitment model (see Defeo 1996a, 1998)
Table 1. Mesodesma mactroides. Model selection for relationship between per capita reproductive rates (number of recruits produced by an adult female) and adult population density. Best model was a negative exponential function with parameters $k=18.46$ and $\beta=-0.014$, where $k=$ maximum number of recruits produced at low densities, and $\beta=$ negative density-dependent effects of adult population. In bold: selected model

\begin{tabular}{|lcc|}
\hline Model & Deviance & $\mathrm{AIC}_{\mathrm{c}}$ \\
\hline Exponential & $\mathbf{1 1 5 . 3 0}$ & $\mathbf{5 7 . 9 8}$ \\
Linear & 138.17 & 59.43 \\
Log-linear & 116.10 & 58.03 \\
\hline
\end{tabular}

The selected models for the age-specific survival rates showed that recruit density (Age 0 group) was the main factor reducing survival rates in all age-classes (Table 2, Fig. 4). The negative effects of the Age 0 recruits on adult survival were stronger for the older age-classes.

The purely density-dependent deterministic model parameterised with the empirical values estimated during the $8 \mathrm{yr}$ study and density-dependent reproductive rates predicted stable dynamics, with an equilibrium density of 421 and 43 ind. $\mathrm{m}^{-2}$ for recruits and adults, respectively. The predicted values for recruits were close to the average observed density (350 ind. $\mathrm{m}^{-2}$, which varied between 122 and $763 \mathrm{~m}^{-2}$ ) but the predicted adult density was lower than that observed (97 ind. $\mathrm{m}^{-2}$, which varied between 19 and $235 \mathrm{~m}^{-2}$ ).

The dynamics of the deterministic skeleton was markedly influenced by the addition of a relatively small amount of stochastic variability to fertility rates, but the predicted dynamics was consistent (in mean values and variability) with the empirical data (Fig. 5).

To each simulated time series we estimated the corresponding spectral densities (Chatfield 1989, Bjørnstad et al. 1996). We summarised the decomposition of the simulated time series by means of the periodogram expressed in terms of frequency $\left(\mathrm{yr}^{-1}\right)$. Because the periodogram is not a good estimator of spectral density when large variances are present, we present the smoothed spectral density using a Gaussian kernel to create weighed averages of the spectra and a lag window of 7 yr. Because our original time series data covered only $8 \mathrm{yr}$, the spectral results of the model outputs represent speculations about the potential real dynamics and should not be considered as proper model validations. The simulated recruitment dynamics displayed a spectral density with no clear dominant frequency; however, biannual and multiannual oscillations with a 3 yr period appear to be important (Fig. 6A). On the other hand, the adult dynamics displayed a spectral density having a multiannual oscillation pattern having a period of around 5 yr (Fig. 6B). 

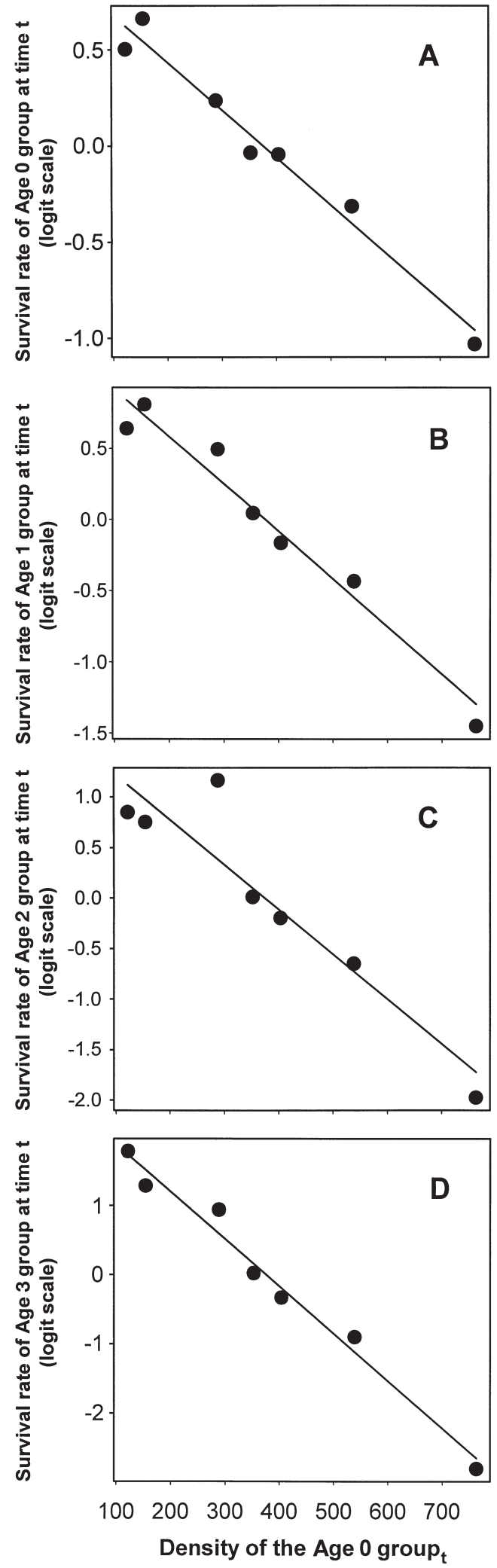

Fig. 4. Mesodesma mactroides. Logit density-dependent models fitted to relationships between survival rates of different age classes and recruit (Age 0 group) density

\section{DISCUSSION}

We developed an age-structured model for the population dynamics of the yellow clam Mesodesma mactroides that includes density-dependent interactions in survival and recruitment and year-to-year variation in reproductive rates. The results strongly suggest that the interaction between the intrinsic system (densitydependent) forces and environmental (density-independent) factors may produce the temporal fluctuations observed in the yellow clam population, with recruitment playing a major role (see also Seijo \& Defeo 1994). Particularly, the model seems to reproduce well yellow clam dynamics for recruits (but predicted adult densities were less than those observed), with density-dependent mechanisms generating a stable equilibrium in the absence of stochastic disturbances.

The estimated negative exponential function for the relationship of the per capita recruitment rates is consistent with the overcompensatory stock-recruitment relationship described by a Ricker's (1954) model published earlier by Defeo (1996a, 1998). This model, which has been used to describe the SRR of molluscs (Hancock 1973) and beetles (Hastings \& Constantino 1987, 1991), suggests overcompensation (i.e. an inhibition of recruitment at high adult densities). In this case, a potential mechanism could be passive filtering of settling larvae by adults, a major process explaining settlement inhibition by established suspension feeders (Woodin 1976, Crowe et al. 1987, André \& Rosenberg 1991, André et al. 1993). Also, sediment-mediated interactions through feeding activity may also change adjacent physical properties of the sediment, thus inhibiting settlement (Rhoads \& Young 1970, Rhoads 1974). Wide variations in fishing intensity generated by the yellow clam fishery closure provided a relatively large range of spawning stock and recruitment sizes, thus enabling a confident SRR estimation with a short time-data series. Our data indicated that adult individuals may suppress recruitment. Consequently, exploitation levels of the adult component of the population may influence intraspecific mechanisms, such as inhibition of recruitment. It is important to note that another potential source of recruitment inhibition by adults in many marine invertebrate populations may be chemical interactions (Rittschof 1990, Satuito et al. 1996); however, they have not been estimated for our study population.

On the other hand, the density-dependent relationships found in survival rates of all age-classes strongly suggest the existence of competitive interactions for both space and resources between individuals. For instance, individual growth rates are negatively related with population density, which strongly suggests 

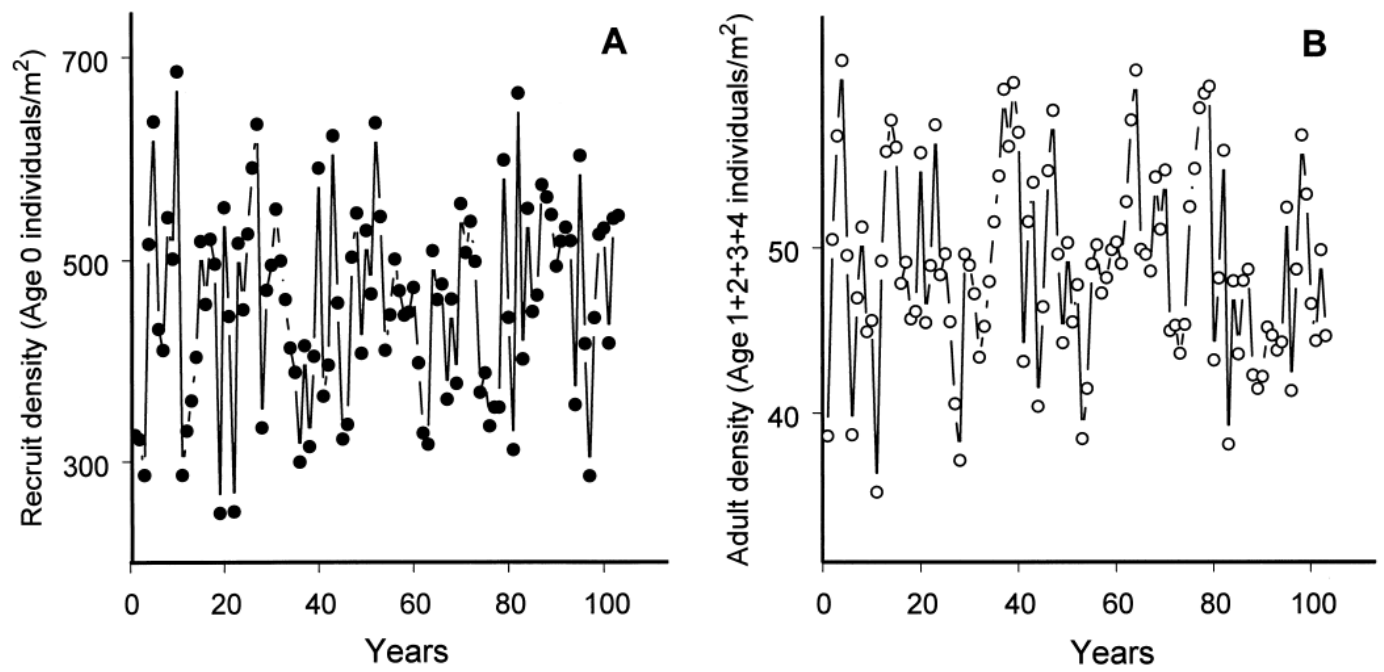

Fig. 5. Mesodesma mactroides. Time trajectories of stochastic model dynamics of Age 0 group (recruits) and adult individuals over $100 \mathrm{yr}$ using fitted parameter values (Tables $1 \& 2$ and 'Results'). Shown are $100 \mathrm{yr}$ of simulation after a transient period of $900 \mathrm{yr}$

Table 2. Mesodesma mactroides. Model selection for linear models describing density-dependent effects on age-specific survival rates. We used 2 functional forms, linear and log-linear, in a logit scale, with binomial error structure and logit link function. Parameters are Intercept, representing density-independent survival rate for each age-class; $\gamma$, representing effects of Age 0 group on age-specific survival rates; and $\mu$, representing density-dependent effects of adult individuals on age-specific survival rates. AIC $\mathrm{C}_{\mathrm{c}}$ = small-sample corrected Akaike information criterion (Hurvich \& Tsai 1989; see Bjørnstad et al. 1995 for detailed explanation in an ecological context). In bold: selected models

\begin{tabular}{|c|c|c|c|c|c|}
\hline Model & Intercept (SE) & $\gamma(\mathrm{SE})$ & $\mu(\mathrm{SE})$ & Deviance & $\mathrm{AIC}_{\mathrm{c}}$ \\
\hline \multicolumn{6}{|l|}{ Age 0 group } \\
\hline \multirow[t]{3}{*}{ Linear } & $-1.457(0.26)$ & $-0.0025(0.0008)$ & - & 0.0514 & 0.223 \\
\hline & $-2.59(0.31)$ & - & $0.0036(0.0026)$ & 0.137 & 7.065 \\
\hline & $-1.736(0.27)$ & $-0.0023(0.0006)$ & $0.0025(0.0014)$ & 0.030 & 10.36 \\
\hline \multirow[t]{3}{*}{ Log-linear } & $1.632(1.40)$ & $-0.69(0.25)$ & - & 0.0706 & 2.45 \\
\hline & $-2.986(1.05)$ & - & $0.174(0.25)$ & 0.162 & 8.26 \\
\hline & $0.92(1.66)$ & $-0.67(0.25)$ & $0.14(0.18)$ & 0.062 & 26.44 \\
\hline \multicolumn{6}{|l|}{ Age 1 group } \\
\hline \multirow{3}{*}{ Linear } & $0.037(0.29)$ & $-0.0033(0.0008)$ & - & 0.132 & 6.81 \\
\hline & $-1.234(0.43)$ & - & $0.0017(0.041)$ & 0.604 & 17.47 \\
\hline & $-0.045(0.39)$ & $-0.0033(0.0009)$ & $0.00082(0.002)$ & 0.127 & 20.57 \\
\hline \multirow[t]{3}{*}{ Log-linear } & $4.04(1.77)$ & $-0.905(0.32)$ & - & 0.238 & 10.95 \\
\hline & -0.923 (1.39) & - & $-0.044(0.34)$ & 0.621 & 17.66 \\
\hline & $4.38(2.31)$ & $-0.92(0.36)$ & $-0.070(0.24)$ & 0.233 & 24.81 \\
\hline \multicolumn{6}{|l|}{ Age 2 group } \\
\hline \multirow[t]{3}{*}{ Linear } & $1.55(0.68)$ & $-0.0044(0.0017)$ & - & 0.819 & 19.60 \\
\hline & $0.172(0.66)$ & - & $-0.0032(0.0066)$ & 1.911 & 25.53 \\
\hline & $1.902(0.85)$ & $-0.0046(0.0019)$ & $-0.0039(0.0047)$ & 0.710 & 35.59 \\
\hline \multirow[t]{3}{*}{ Log-linear } & $6.95(3.61)$ & $-1.20(0.62)$ & - & 1.16 & 22.04 \\
\hline & $1.95(2.03)$ & - & $-0.51(0.50)$ & 1.67 & 24.61 \\
\hline & $9.24(4.17)$ & $-1.26(0.64)$ & $-0.529(0.41)$ & 0.639 & 33.77 \\
\hline \multicolumn{6}{|l|}{ Age 3 group } \\
\hline \multirow[t]{3}{*}{ Linear } & $3.30(0.56)$ & $-0.0068(0.0013)$ & - & 0.280 & 11.91 \\
\hline & $0.76(0.82)$ & - & $-0.0023(0.0008)$ & 2.53 & 27.51 \\
\hline & $3.46(0.64)$ & $-0.0068(0.0013)$ & $-0.0026(0.0038)$ & 0.253 & 25.38 \\
\hline \multirow[t]{3}{*}{ Log-linear } & $14.47(3.82)$ & $-2.36(0.64)$ & - & 0.520 & 16.32 \\
\hline & $2.43(2.51)$ & - & $-0.46(0.60)$ & 2.328 & 26.91 \\
\hline & $15.30(3.52)$ & $-2.22(0.52)$ & $-0.44(0.33)$ & 0.370 & 28.05 \\
\hline
\end{tabular}



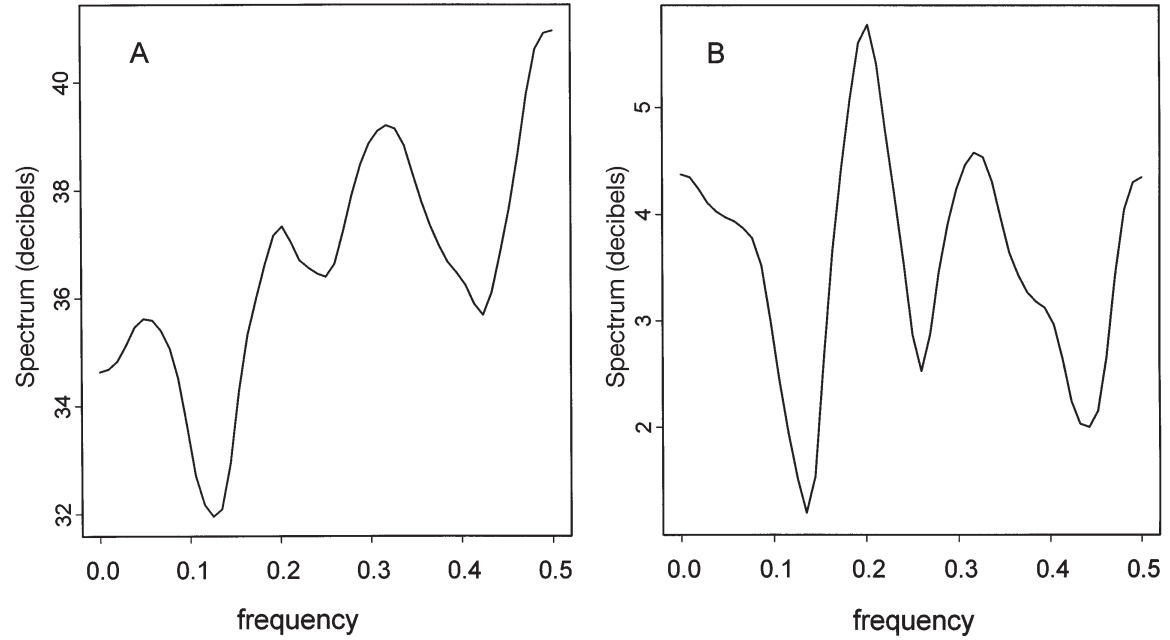

Fig. 6. Mesodesma mactroides. Spectral density of (A) recruit (Age 0 group) and (B) adult (Ages $1+2+3+4)$ dynamics. Lines represent smoothed spectral density to create weighed averages of spectra using a lag window of 7 yr. Smoothed periodograms are on a $10^{\circ} \log$ scale, where unit is decibels. Smoothing was done using Splus function spectrum with span of the modified Daniel window specified as $\mathrm{c}(7,7)$ (see Venables \& Ripley 1997)

the existence of competitive interactions for resources (Defeo 1998). However, the nature of this interaction seems to be highly asymmetrical; adult survival rates are reduced due to intercohort interactions. The main factor decreasing survival rates of adult individuals is the density of the Age 0 group (recruits), while survival rates of the Age 0 group are reduced by intracohort interactions. One of the possible reasons is that recruit density comprises on average $78 \%$ of the total yellow clam population; thus, the total effect of this age-class may be the most important intra-specific competitive force within the population.

It is widely known that fluctuations in population density may be caused by delays in these regulatory mechanisms (Royama 1992, Turchin \& Taylor 1992). These regulatory delays may be divided into 2 categories (see Bjørnstad et al. 1998, 1999): (1) those caused by symmetric interactions between similar individuals (same age or stage); (2) those caused by asymmetric interactions between individuals of different ages (adults vs recruits). Our results seem to support the existence of both kinds of individual interaction in the yellow clam population. While the number of adults appears to reduce recruitment via passive filtering of settling larvae by adults, the Age 0 group (recruits) appears to reduce the survival rate of the other age-classes via competitive interactions.

Another integral part of the yellow clam population dynamics is the stochastic components of the system represented by climatic and oceanographic variables. For instance, large salinity variations seem to have strong effects on population dynamics of this species (Defeo 1998); e.g., the concurrent effects of an intense freshwater discharge from the Andreoni Canal and a high harvesting level that peaked in 1985 seem to be responsible for the drastic reduction in adult density and recruitment failure in 1986 (Defeo 1993). These factors also affected sympatric unharvested clams in the same study area (Defeo \& de Alava 1995, Defeo 1998). In addition to the above meso-scale (sensu Orensanz \& Jamieson 1998) effects of salinity and harvesting, large-scale massive mortality of the yellow clam occurred throughout the entire geographic distribution area of the species, including thousands of kilometers of sandy beaches in Brazil, Uruguay and Argentina (Méndez 1995, Odebrecht et al. 1995). This mass mortality was attributed to the passage of cold atmospheric fronts and the consequent extremely dense accumulation of dinoflagellates in the surf-zone. Since these massive mortality events, Mesodesma mactroides populations throughout its biogeographic distribution range have not been recovered (Defeo unpubl. data). It is important to note that we define meso-scale (intermediate scale) in this study as the spatial relation between populations within a metapopulation. This is typically the scale of fishing grounds and beds within which homogeneity assumptions with regards to the fishing process and/or dynamics of harvested stocks are made in classical theory (Orensanz \& Jamieson 1998).

Some inter- and intracohort interactions such as the passive filtering of larvae or intraspecific competition for food or space might increase the dimensionality and thus the complexity of yellow clam population dynamics (Turchin \& Taylor 1992, Dennis et al. 1995, Constantino et al. 1997, Stenseth et al. 1999). In fact, both intra- and intercohort interactions and stochastic forces acting together can produce complex population dynamic patterns, characterised by a bimodal spectrum with both cycles and low-frequency dynamics (Bjørnstad et al. 1999, Stenseth et al. 1999). It is well known that sustained population cycles may be produced when interactions between individuals are highly non-linear, or when weakly non-linear or linear dynamics are disrupted by stochastic disturbances (see Nisbet \& Gurney 1982, Royama 1992, Stenseth et al. 1996). In the yellow clam, the density-dependent survival functions were weakly non-linear or almost lin- 
ear, while the density-dependent recruitment was non-linear. In this context, some of the between-year variability observed in recruitment of some marine benthic invertebrates may be the result of deterministic components (density-dependence) interacting with environmental factors. Recently, Bjørnstad et al. (1999) and Stenseth et al. (1999) showed that stochastic forces in recruitment can interact with the age-structure of a marine fish population, and that log autoregressive moving average (ARMA) models can be useful to represent the ecological processes behind such dynamic patterns. In fact, our age-structured model for the yel-

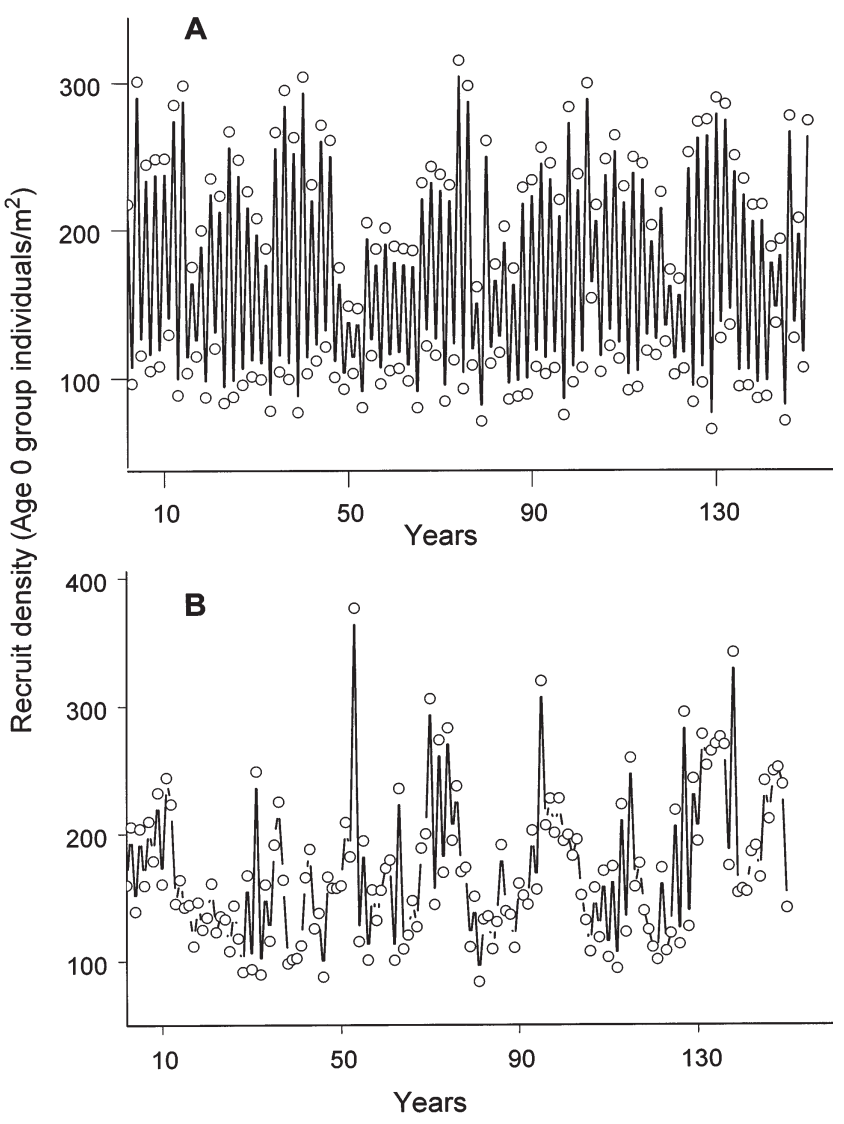

Fig. 7. Mesodesma mactroides. Simulated trajectories of Age 0 group (recruits) under 2 different scenarios: (A) simulating population system with weak effects of adult individuals on Age 0 group and strong effects of Age 0 group on adult individuals (by reducing density-dependent coefficient in reproductive rates from -0.014 to -0.0014 and increasing densitydependent effects of Age 0 group on adult survival by a factor of 10); (B) simulating population system with strong effects of adult individuals on Age 0 group and no effects of Age 0 group on adult individuals (by using estimated densitydependent coefficient in reproductive rates, and assuming that adults [Age Groups $1+2+3+4$ and no Age 0 group] reduce survival in all age-classes, and increasing estimated coefficients by a factor of 10). Shown are $150 \mathrm{yr}$ of simulation after a transient period of $850 \mathrm{yr}$ low clam can be rewritten in delay-co-ordinates to obtain a simplified model for the Age 0 group, which can be represented by an ARMA $(3,1)$ process. Moving average processes are capable to generate low frequency dynamics (Chatfield 1989, see Stenseth et al. 1999 for an ecological example). However, our model simulations did not exhibit low-frequency dynamics, and only short-term frequencies were observed (cycles). In fact, the spectral density showed biannual and $3 \mathrm{yr}$ oscillations as the main components of variation in recruit dynamics, indicating that stochastic forces (white noise) and density-dependent forces may interact to produce recruitment variability, but there would be no resonant effects of stochastic variability. One possible cause may be that the estimated intra- and intercohort interactions are too weak to give rise to more complex dynamics, or the negative effects of the Age 0 group on adult survival may be counterbalanced by the negative effects of the adults on recruitment. We explored these alternatives by simulating a yellow clam population with strong asymmetric interactions. First, we simulated a population system with weak effects of adult individuals on the Age 0 group and strong effects of the Age 0 group on adult individuals (by reducing the density-dependent coefficient reproductive rates from -0.014 to -0.0014 and increasing the density-dependent effects of Age 0 group on adult survival by a factor of 10). Second, we simulated a population system with strong effects of adult individuals on the Age 0 group and no effects of the Age 0 group on adult individuals (by using the estimated densitydependent coefficient in reproductive rates, and assuming that adults reduce Age 0 group survival). Fig. 7 shows 150 yr of simulation after an 850 yr transient period was discarded. This simulation showed that a yellow clam population with strong intercohort interactions is capable of exhibiting both cycles and low-frequency dynamics (Fig. 8) similar to those observed in cod populations (Bjørnstad et al. 1999, Stenseth et al. 1999). Simulations of simple deterministic and stochastic models predict that spectra will be dominated by high-frequency (short-term) dynamics (Cohen 1995, Engen \& Lande 1996, White et al. 1996). However, most real populations are also characterised by low-frequency dynamics (Cohen 1995, Sugihara 1995, 1996, Halley 1996, White et al. 1996). Consequently, the effects of some long-term environmental forcing have been argued as the factor explaining the existence of long-term dynamics in natural populations (Halley 1996). However, recent studies have shown that low-frequency dynamics could be generated by intrinsic (density-dependent) mechanisms in combination with uncorrelated stochastic processes (Miramontes \& Rohani 1998, Bjørnstad et al. 1999, Stenseth et al. 1999). 

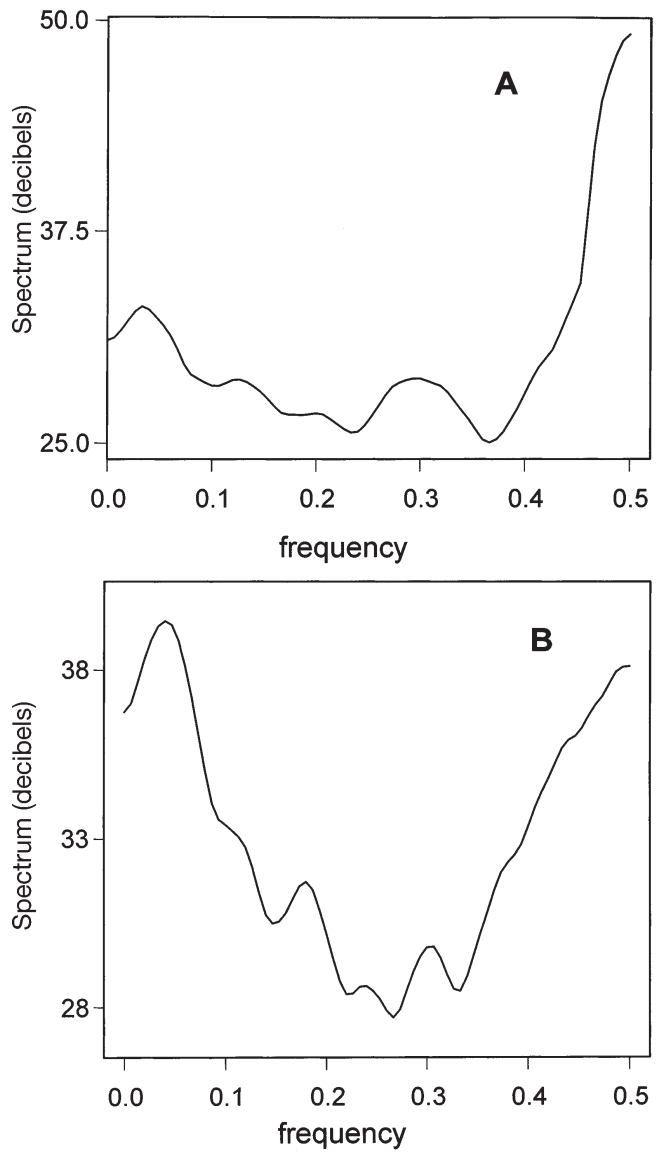

Fig. 8. Mesodesma mactroides. Spectral density of Age 0 group of model simulations in Fig. 7. In both cases U-shaped spectra indicate presence of cycles (short-term frequencies) and low-frequency dynamics. Smoothed periodograms are given on a $10^{\circ} \log$ scale, where unit is decibels. Smoothing was done using S-plus function spectrum with span of the modified Daniel window specified as $\mathrm{C}(7,7)$ (see Venables \& Ripley 1997)

The yellow clam population at Barra del Chuy exhibited important temporal fluctuations that could be explained by the occurrence of uncorrelated environmental disturbances and density-dependent factors. The non-linear mechanisms modelled for the first time in a sandy beach population suggest that recruitment variability may often be caused by biological interactions (density-dependent recruitment by adult density [Age Groups $1+2+3+4$ ] and survival limitation by recruit [Age 0 group] density) interacting with uncorrelated environmental disturbances. On the other hand, we modelled environmental variability as white noise, whereas external environmental factors such as oceanographic conditions and El Niño events could be better described by another random distributed variable; these possible effects should be considered in future studies.
Acknowledgements. M.L. acknowledges FONDECYT 3980042 and O.D. acknowledges CONICYT 1018 and 4034. We also thank Ottar N. Bjørnstad and 3 anonymous reviewers for their helpful comments that improved the manuscript.

\section{LITERATURE CITED}

André C, Rosenberg R (1991) Adult-larval interactions in the suspension-feeding bivalves Cerastoderma edule and Mya arenaria. Mar Ecol Prog Ser 71:227-234

André C, Jonsson PR, Lindegarth M (1993) Predation on settling bivalve larvae by benthic suspension feeders: the role of the hydrodynamics and larval behaviour. Mar Ecol Prog Ser 97:183-192

Andrewartha, HG, Birch LC (1954) The distribution and abundance of animals. Chicago University Press, Chicago

Arntz WE, Brey T, Tarazona J, Robles A (1987) Changes in the structure of a shallow sandy-beach community in Peru during an El Niño event. S Afr J Mar Sci 645-658

Bachelet G (1986) Recruitment and year-to-year variability in a population of Macoma balthica. Hydrobiologia 142: 233-248

Bertness MD, Gains SD, Stephans EG, Yund PO (1992) Components of recruitment in populations of the acorn barnacle Semibalanus balanoides (Linnaeus). J Exp Mar Biol Ecol 156:199-215

Bjørnstad ON, Falck W, Stenseth NC (1995) A geographical gradient in small rodent density fluctuations: a statistical modelling approach. Proc R Soc (Ser B) 262:127-133

Bjørnstad ON, Champely S, Stenseth NC, Saitoh S (1996) Cyclicity and stability of grey-sided voles (Clethrionomys rufocanus), of Hokkaido: spectral and principal components analyses. Proc R Soc (Ser B) 351:867-875

Bjørnstad ON, Begon M, Stenseth NC, Falck W, Sait SM, Thompson DJ (1998) Population dynamics of the Indian meal moth: demographic stochasticity and delayed regulatory mechanisms. J Anim Ecol 67:110-126

Bjørnstad ON, Fromentin JM, Stenseth NC, Gjøsæter J (1999) Cycles and trends in cod populations. Proc Natl Acad Sci USA 96:5066-5071

Bodenheimer FS (1938) Problems of animal ecology. Oxford University Press, Oxford

Botsford LW (1986) Effects of environmental forcing on agestructured populations: northern California Dungeness crab (Cancer magister) as an example. Can J Fish Aquat Sci 43:3245-2352.

Botsford LW (1997) Dynamics of populations with densitydependent recruitment and age structure. In: Tuljapurkar S, Caswell H (eds) Structured-population models in marine, terrestrial, and freshwater systems. Chapman \& Hall, New York, p 371-408

Brazeiro AP, Defeo O (1999) Effects of harvesting and densitydependence on the demography of sandy beach populations: the yellow clam Mesodesma mactroides of Uruguay. Mar Ecol Prog Ser 182:127-135

Caswell H (1989) Matrix population models: construction, analysis and interpretation. Sinauer, Sunderland, MA

Chatfield C (1989) The analysis of time series. An introduction. Chapman \& Hall, London

Cohen JE (1995) Unexpected dominance of high frequencies in chaotic nonlinear population models. Nature 378: $610-612$

Connell JH (1985) The consequences of variation in initial settlement vs. post-settlement mortality in rocky intertidal communities. J Exp Mar Biol Ecol 93:11-45

Constantino RF, Desharnais RA, Cushing JM, Dennis B (1997) 
Chaotic dynamics in an insect population. Science 275: 389-391

Crowe WA, Josefson AB, Svane I (1987) Influence of adult density on recruitment into soft sediments: a short-term in situ sublittoral experiment. Mar Ecol Prog Ser 41:61-69

Cushing D (1995) Population production and regulation in the sea: a fisheries perspective. Cambridge University Press, New York

Defeo O (1989) Development and management of artisanal fishery for the yellow clam Mesodesma mactroides in Uruguay. Fishbyte 7:21-25

Defeo O (1993) Reproduction of coastal invertebrates through the management on natural areas: a successful example. Out of the Shell 3:11-13

Defeo O (1996a) Experimental management of an exploited sandy beach bivalve population. Rev Chil Hist Nat 69: 605-614

Defeo O (1996b) Recruitment variability in sandy beach macroinfauna: much to learn yet. Rev Chil Hist Nat 69:615-630

Defeo O (1998) Testing hypotheses on recruitment, growth and mortality in exploited bivalves: an experimental perspective. Can Spec Publ Fish Aquat Sci 125:257-264

Defeo O, de Alava A (1995) Effects of human activities on long-term trends in sandy beach populations: the wedge clam Donax hanleyanus in Uruguay. Mar Ecol Prog Ser 123:73-82

Defeo O, Layerle C, Masello A (1986) Spatial and temporal structure of the yellow clam Mesodesma mactroides (Deshayes, 1854) in Uruguay. Medio Ambiente 8:48-57

Defeo O, Jaramillo E, Lyonnet A (1992a) Community structure and intertidal zonation of the macroinfauna in the Atlantic coast of Uruguay. J Coast Res 8:830-839

Defeo O, Ortiz E, Castilla JC (1992b) Growth, mortality and recruitment of the yellow clam Mesodesma mactroides in Uruguayan beaches. Mar Biol 114:429-437

Dennis B, Desharnais RA, Cushing JM, Constantino RF (1995) Nonlinear demographic dynamics: mathematical models, statistical methods, and biological experiments. Ecol Monogr 65:261-281

Desharnais RA, Liu L (1987) Stable demographic limit cycles in laboratory populations of Tribolium castaneum. J Anim Ecol 56:885-906

Eberhardt LL (1988) Using age-structure data from changing populations. J Appl Ecol 25:373-378

Engen S, Lande R (1996) Population dynamic models generating the lognormal species abundance distribution. Mathl Biosci 132:169-184

Gaines S, Roughgarden J (1985) Larval settlement rate: a leading determinant of structure in an ecological community of the marine intertidal zone. Proc Natl Acad Sci USA 82:3707-3711

Guillou J (1982) Variabilite des populations de Donax trunculus et Donax vittatus en Baie de Douarnennez. Neth J Sea Res 16:264-269

Gurney WSC, Nisbet RM (1985) Fluctuation periodicity, generation separation, and the expression of larval competition. Theor Popul Biol 28:150-180

Gurney WSC, Blyth SP, Nisbet RM (1980) Nicholson blowflies revisited. Nature 287:17-21

Halley JM (1996) Ecology, evolution and 1/f-noise. Trends Ecol Evol 11:33-37

Hancock DA (1973) The relationship between stock and recruitment in exploited invertebrates. Rapp P-V Reun Cons Int Explor Mer 164:113-131

Hastings A, Constantino RF (1987) Cannibalistic egg-larva interactions in Tribolium: an explanation for the oscillations in population numbers. Am Nat 130:36-52
Hastings A, Constantino RF (1991) Oscillations in population numbers: age-dependent cannibalism. J Anim Ecol 60: 471-482

Higgins K, Hastings A, Bostford, LW (1997a) Density dependence and age structure: nonlinear dynamics and population behavior. Am Nat 149:247-269

Higgins K, Hastings A, Sarvela JN, Bostford LW (1997b) Stochastic dynamics and deterministic skeletons: population behavior of Dungeness crab. Science 276:1431-1434

Hughes TP (1990) Recruitment limitation, mortality, and population regulation in open systems: a case study. Ecology 71:12-20

Hunt HL, Scheibling RE (1997) Role of early post-settlement mortality in recruitment of benthic marine invertebrates. Mar Ecol Prog Ser 155:269-301

Hurvich CM, Tsai CL (1989) Regression and time series model selection in small samples. Biometrika 76:297-307

Leirs H, Stenseth NC, Nichols JD, Hines JE, Verhagen R, Verheyen W (1997) Stochastic seasonality and nonlinear density-dependent factors regulate population size in an African rodent. Nature 389:176-180

Leslie PH (1945) On the use of matrices in certain population mathematics. Biometrika 33:183-212

Lima M, Keymer JE, Jaksic FM (1999) ENSO-driven rainfall variability and delayed density-dependence cause rodent outbreaks in western South America: linking demography and population dynamics. Am Nat 153:479-491

Liu L, Cohen JE (1987) Equilibrium and local stability in a logistic matrix models for age-structured populations. J Math Biol 25:73-88

Masello A, Defeo O (1986) Determinación de la longitud de primera madurez sexual en Mesodesma mactroides (Deshayes, 1854). Commun Soc Malacol Uruguay 6:387-392

McCullagh P, Nelder JA (1989) Generalized linear models. Chapman \& Hall, New York

Méndez S (1995) Bivalve mortality on southwest Atlantic shores. Harmful Algae News 10/11:1-12

Menge BA (1991) Relative importance of recruitment and other causes of variation in rocky intertidal community structure. J Exp Mar Biol Ecol 146:69-100

Miramontes O, Rohani P (1998) Intrinsically generated coloured noise in laboratory insect populations. Proc R Soc (Ser B) 265:785-792

Nakaoka M (1993) Yearly variation in recruitment and its effects on population dynamics in Yoldia notabilis (Mollusca: Bivalvia) analyzed using projection matrix model. Res Popul Ecol 35:199-213

Nakaoka M (1996). Dynamics of age- and size-structured populations in fluctuating environments: applications of stochastic matrix models to natural populations. Res Popul Ecol 38:141-152

Nakaoka M (1997) Demography of the marine bivalve Yoldia notabilis in fluctuating environments: an analysis using a stochastic matrix model. Oikos 79:59-68

Nicholson AJ (1933) The balance of animal populations. J Anim Ecol 2:132-178

Nisbet RM, Gurney WSC (1982) Modeling fluctuating populations. John Wiley \& Sons, Chichester

Odebrecht C, Rörig L, Garcia VT, Abreu PC (1995) Shellfish mortality and a red tide event in southern Brazil. In: Lassus P, Arzul G, Erard E, Gentien P, Marcaillou C (eds) Harmful marine algal blooms. Technique et Documentation, Lavoisier, Intercept Ltd, Paris, p 213-218

Orensanz J, Jamieson, G (1998) The assessment and management of spatially structured stocks. Can Spec Publ Fish Aquat Sci 125:441-459

Pearson CH, Munro JL (1991) Growth, mortality and recruit- 
ment rates of giant clams, Tridacna gigas and T. Derasa, at Michaelmas Reef, central Great Barrier Reef, Australia. Aust J Mar Freshw Res 42:241-262

Peterson CH, Summerson HC (1992) Basin-scale coherence of population dynamics of an exploited marine invertebrate, the bay scallop: implications of recruitment limitation. Mar Ecol Prog Ser 90:257-272

Pineda J (1991) Predictable upwelling and the shoreward transport of planktonic larvae by internal tidal bores. Science 253:548-551

Pineda J, Caswell H (1997) Dependence of settlement rates on suitable substrate area. Mar Biol 129:541-548

Raimondi PT (1990) Patterns, mechanisms, consequences of variability in settlement and recruitment of an intertidal barnacle. Ecol Monogr 60:83-309

Rhoads DC (1974) Organism-sediment relations on the muddy sea floor. Oceanogr Mar Biol Annu Rev 12:263-300

Rhoads DC, Young DK (1970) The influence of deposit-feeding organisms on sediment stability and community trophic structure. J Mar Res 28:150-178

Ricker WE (1954) Stock and recruitment. J Fish Res Board Can 11:559-623

Rittschof D (1990) Peptide-mediated behaviours in marine organisms. Evidence for a common theme. J Chem Ecol 16:261-272

Royama T (1992) Analytical population dynamics. Chapman \& Hall, London

Rumrill S (1989) Population size-structure, juvenile growth, and breeding periodicity of the sea star Asterina miniata in Barkley Sound, British Columbia. Mar Ecol Prog Ser 56: 37-47

Sakamoto Y, Ishiguro, M, Kitagawa, G (1986) Akaike information criterion statistics. KTK Scientific Publishers, Tokyo

Satuito CG, Shimizu K, Fusetani N (1996) Studies on the factors influencing larval settlement in Balanus amphitrite and Mytilus galloprovincialis. Hydrobiologia 358:275-280

Seijo JC, Defeo O (1994) Dynamics of resource and fishermen behaviour in coastal invertebrate fisheries. In: Antona E, Catanzano J, Sutinen JG (eds) Proceedings of the VI Conference of the International Institute of Fisheries Economics and Trade. FAO Fisheries Technical Paper, Rome, p 209-222

Editorial responsibility: Otto Kinne (Editor), Oldendorf/Luhe, Germany
Shimada M, Tuda M (1996) Delayed density-dependence and oscillatory population dynamics in overlapping-generation systems of a seed beetle Callosobruchus chinensis: matrix population model. Oecologia 105:116-125

Stenseth NC, Bjørnstad ON, Saitoh T (1996) A gradient from stable to cyclic populations of Clethrionomys rufocanus in Hokkaido, Japan. Proc R Soc (Ser B) 263:1117-1126

Stenseth NC, Bjørnstad ON, Falck W, Fromentin JM, Gjøsæter J, Gray JS (1999) Dynamics of coastal cod populations: intra- and intercohort density-dependence and stochastic processes. Proc R Soc Lond B 266:1645-1654

Sugihara G (1995) From out of the blue. Nature 378:p 559

Sugihara G (1996) Red/blue chaotic power spectra. Nature 381:p 199

Sutherland JP (1990): Recruitment regulates demographic variation in a tropical intertidal barnacle. Ecology 71: 955-972

Thorson G (1950) Reproductive and larval ecology of marine bottom invertebrates. Biol Rev 25:1-45

Turchin P (1995) Population regulation: old arguments and a new synthesis. In: Capuccino N, Price PW (eds) Population dynamics: new approaches and synthesis. Academic Press, San Diego, p 19-40

Turchin P, Taylor AD (1992) Complex dynamics in ecological time series. Ecology 73:289-305

Underwood AJ, Denley EJ (1984) Paradigms, explanation and generalisations in models for the structure of intertidal communities on rocky shores. In: Strong DR, Simberloff D (eds) Ecological communities: conceptual issues and the evidence. Princeton University Press, Princeton, p 151-180

Vahl O (1982) Long-term variations in recruitment of the Iceland scallop, Chlamys islandica from northern Norway. Neth J Sea Res 16:80-87

Venables WN, Ripley BD (1997) Modern applied statistics with S-PLUS. Springer-Verlag, New York

White A, Begon M, Bowers RG (1996) Explaining the colour of power spectra in chaotic ecological models. Proc R Soc (Ser B) 263:1731-1737

Woodin SA (1976) Adult-larval interactions in dense infaunal assemblages: patterns of abundance. J Mar Res 34:25-41

Submitted: November 16, 1999; Accepted: May 30, 2000

Proofs received from author(s): November 8, 2000 